\title{
Response of Cucumber (Cucumis sativus L.) and Squash (Cucurbita pepo L. var. melopepo) Roots to Chilling Stress during Early Stages of Seedling Development
}

\author{
Eleazar Reyes and Paul H. Jennings \\ Department of Horticulture, Forestry and Recreation Resources, Kansas State University, Manhattan, \\ KS 66502
}

Additional index words. relative water content, ion determination, conductivity, absorbance, chilling sensitivity

\begin{abstract}
Roots of 'Golden Girl' squash (Cucurbita pepo var. melopepo) and 'Encore' cucumber (Cucumis sativus L.), 4and 3-days-old, respectively, were exposed to 2, 6, 10, and 15C for 24, 48, 96, 144, and 192 hours to compare the sensitivity to chilling temperatures and the subsequent recovery at more favorable temperatures. Seedlings were more sensitive to chilling at 2 and $6 \mathrm{C}$ when measured by their ability to resume growth when returned to $26 \mathrm{C}$. Root growth decreased after 48 hours of chilling. Seedlings stressed at 10 and $15 \mathrm{C}$ were able to continue root growth at these temperatures and when returned to $26 \mathrm{C}$. However, seedlings at $10 \mathrm{C}$ exhibited root-tip browning in both crop species, suggesting disfunction in metabolic pathways that were repressed in seedlings growing at $2 \mathrm{C}$ where those symptoms were not present. Effects on root dry weight occurred in the first 24 hours at all temperatures studied. After 96 hours of treatment, seedlings grown at 2 and $6 \mathrm{C}$ were irreversibly damaged, as evidenced by their inability to resume growth when returned to 26C. Leakage of electrolytes from squash and cucumber roots increased after 48 hours at $2 \mathrm{C}$. Potassium, $\mathrm{Na}^{+}$, and $\mathrm{PO}_{4}^{-2}$ were lost in greater amounts than $\mathrm{Mg}^{+2}, \mathrm{Cl}^{-}$, and $\mathrm{SO}_{4}^{-2}$. No difference in ionic leakage occurred at 10 and $15 \mathrm{C}$, and $\mathrm{Ca}^{+2}$ leakage was not detected at any chilling stress temperature.
\end{abstract}

Seed germination and seedling development are critical stages during crop establishment. Chilling temperatures are a major contributing factor to poor stand establishment in cold soils and result in economic losses (Bradow 1990a, 1990b). Growth reduction, wilting, necrosis, and delayed maturity are often reported as symptoms of chilling injury (Bolger et al., 1992; Herner, 1990; Markhart, 1986; Wolk and Herner, 1982).

Chilling injury is defined as damage caused by physiological and biochemical alterations induced by temperatures above the freezing point but below 12C (Raison and Lyons, 1986; Saltveit and Morris, 1990). Many economically important crops such as corn, tomato, squash, cucumber, and cotton are chilling-sensitive during vegetative and reproductive growth (Jackman et al., 1988; Markhart, 1986; Wang, 1990).

Roots of germinating seedlings are sensitive to chilling temperatures (Bennett et al., 1992). Responses of roots to chilling include a decrease in water uptake presumably due to reductions in root conductance (Bolger et al., 1992; Markhart et al., 1979; McWilliam et al., 1982), leakage of endogenous solutes due to loss of membrane integrity (Mistrik et al., 1992), growth reduction caused by alterations in the balance existing between cell production and differentiation (Barlow and Adam, 1989; Bradow, 1990a), and induction of a differential response in the capacity to resume growth when warm temperatures are restored (Bradow, 1990b).

Cells of Zea mays primary roots exposed to $4 \mathrm{C}$ exhibited modifications in the cytoplasm and in the nucleolus (Crevecoeur et al., 1983). Nuclei of soybean radicle chilled at $4 \mathrm{C}$ developed an irregular shape, and mitochondria showed weakly defined envelopes and cristae (Chabot and Leopold, 1985). Other studies have reported mitochondrial swelling, an increase in rough endoplasmic reticulum, discontinuity of the tonoplast, and the subcellular deposition of crystalline compounds in roots of Episcia reptans

Contribution no. 94-160-J from the Kansas Agriculture Experiment Station. The cost of publishing this paper was defrayed in part by the payment of page charges. Under postal regulations, this paper therefore must be hereby marked advertisement solely to indicate this fact. exposed to 5 to $15 \mathrm{C}$ for 1 to $50 \mathrm{~h}$ (Davies and Wilson, 1984; Kimball and Salisbury, 1973). Changes in cell wall structure in Prunus persica (L.) Batsch stored at 5 to $10 \mathrm{C}$ were associated with dissolution of the middle lamella and plasmolysis of the parenchyma cells (Luza et al., 1992).

Seedling roots often are exposed to cold soil temperatures, especially when planted early in the growing season. Soil temperatures tend to change more slowly than air temperatures, and, therefore, roots may experience chilling conditions over several days. Additional research is needed to understand how roots react under these conditions and the subsequent effects on root development when more favorable temperatures return (Davies and Wilson, 1984; Herner, 1990). This study was initiated to compare the sensitivity of squash and cucumber seedlings roots to chilling temperatures.

\section{Materials and Methods}

Plant material. 'Encore' cucumber and 'Golden Girl' squash seeds were purchased from Harris Seeds (Rochester, N.Y.).

Preparation and growing conditions of seeds. Seeds were washed in a 1:10 (v/v) dilution of commercial sodium hypochlorite, rinsed 20 times with distilled water and placed in plastic containers $(32 \times 26 \times 12 \mathrm{~cm})$ lined with paper towels saturated with distilled water. The containers were placed in a $26 \mathrm{C}$ incubator for either 3 days (cucumbers) or 4 days (squash).

Chilling treatments. Chilling stress was imposed in low temperature incubators in the dark for 24, 48, 96, 144, and $192 \mathrm{~h}$. The temperature treatments were $2,6,10$, and $15 \mathrm{C}$.

Postchilling treatments. A sample of 25 seedlings was transferred to $26 \mathrm{C}$ after each period of chilling and from each temperature. Seedlings were allowed to grow for $24 \mathrm{~h}$ before measurements were taken. A separate set of seedlings was given a stepwise temperature increase to observe the effect of chilling after a gradual increase in temperature after chilling. The recovery period was $8 \mathrm{~h}$ each at 10,18 , and $26 \mathrm{C}$ for seedlings chilled at $2 \mathrm{C}$, and 12 $\mathrm{h}$ at 18 and $26 \mathrm{C}$ for seedlings chilled at $10 \mathrm{C}$. 
Dry-weight determination. Excised roots from each treatment were weighed after $24 \mathrm{~h}$ in a drying oven at $75 \mathrm{C}$.

Solute leakage analysis. Roots from each cultivar were excised, washed twice with deionized water, placed in 100-ml flasks with $60 \mathrm{ml}$ deionized water, and shaken on a rotary shaker at $26 \mathrm{C}$ for 2 h. A 1-ml aliquot was taken to measure leakage of organic compounds at $280 \mathrm{~nm}$ using a spectrophotometer (model U-1100; Hitachi, Tokyo). The electrical conductivity of the remaining solution was measured with a conductance-resistance meter (model 34; YSI, Yellow Springs, Ohio). Values are expressed on a dry-weight basis. The relative water content (RWC) of 21 cucumber seedling roots chilled for $24,48,72$, and $96 \mathrm{~h}$ at 2,10 , and $15 \mathrm{C}$ was obtained using the methodology described by Barrs and Weatherley (1962). Samples were kept in the dark for $4 \mathrm{~h}$ before measuring RWC.

Characterization of ion leakage. Seedlings of cucumber and squash were chilled at 2,10 , and $15 \mathrm{C}$ for either 24 or $144 \mathrm{~h}$ to quantify specific ionic leakage from roots. Twenty-five ml leachate from a sample of 25 roots in $60 \mathrm{ml}$ deionized water was analyzed by atomic absorption spectrometry for $\mathrm{Ca}^{+2}, \mathrm{Na}^{+}, \mathrm{K}^{+}, \mathrm{Mg}^{+2}, \mathrm{Cl}^{-}$, $\mathrm{PO}_{4}^{-2}, \mathrm{SO}_{4}^{-2}$, and $\mathrm{NO}_{3}^{-}$. Values are expressed on a dry-weight basis.

Statistical analysis. All experiments were conducted as a randomized complete design with factorial arrangement. Each treatment was replicated three times.

\section{Results}

Visual symptom development. Preliminary studies confirmed, as reported by Herner (1990), that seeds of squash and cucumber are not sensitive to chilling injury during imbibition (data not

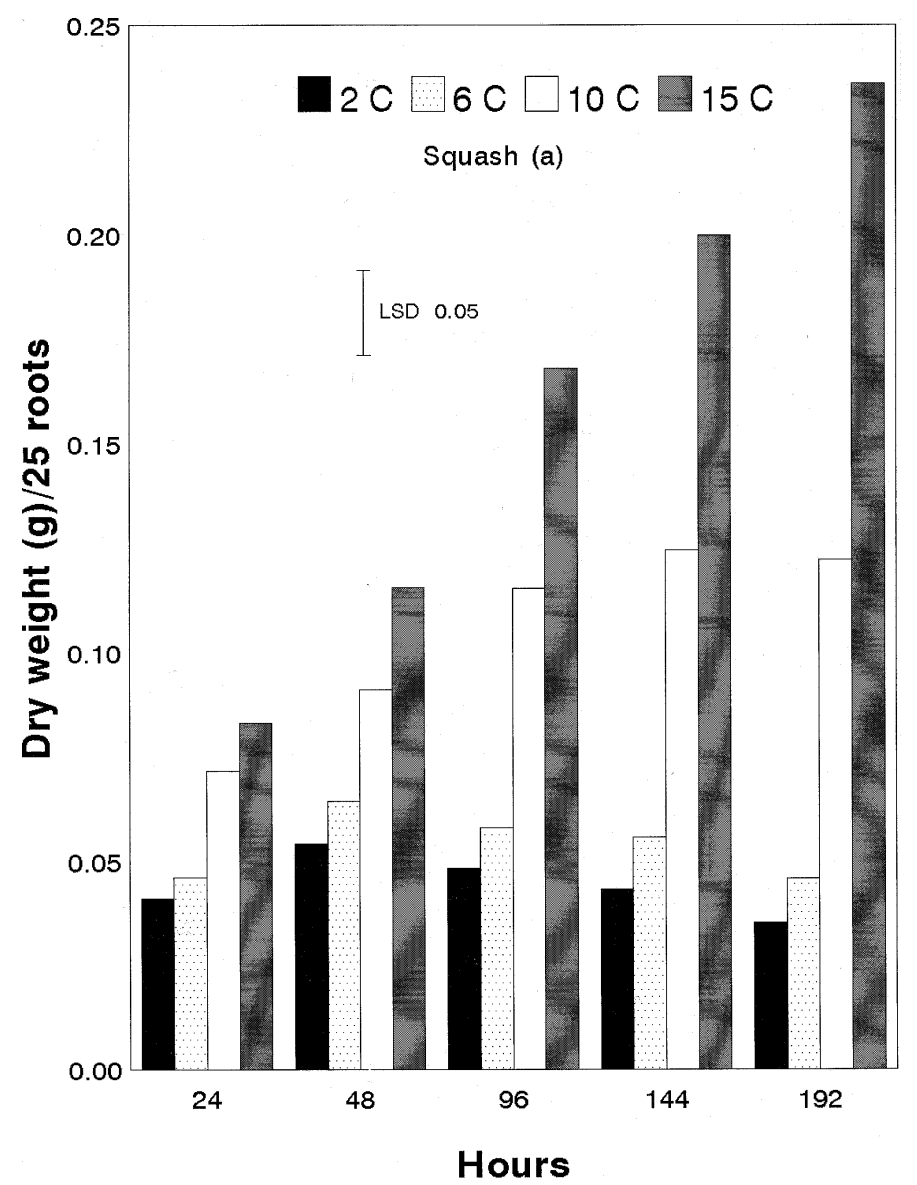

presented). However, seeds imbibed at $2 \mathrm{C}$ for periods up to $144 \mathrm{~h}$ and then transferred to $26 \mathrm{C}$ initiated root growth but at a slower rate than seed treated at 10 or $15 \mathrm{C}$.

Roots of 3- and 4-day-old germinated seeds were more sensitive to chilling than younger seedlings. Visual symptoms of injury included root flaccidity and collapse of root tissue when seedlings were returned to $26 \mathrm{C}$. Root tips, root hairs, and smaller lateral roots were all sensitive to chilling stress.

Root exudates were observed at $2 \mathrm{C}$ and browning of root tips occurred at $10 \mathrm{C}$ in both crops after $48 \mathrm{~h}$ of chilling. Roots chilled at $2 \mathrm{C}$ for periods longer than $96 \mathrm{~h}$ were irreversibly injured and unable to recover. Return of seedlings to $26 \mathrm{C}$ accelerated the development of these symptoms.

Effect of chilling on root dry weight $(D W)$. Root growth in both species as measured by the change in DW was greater in both species after exposure to 10 and $15 \mathrm{C}$ as compared to 2 and $6 \mathrm{C}$ (Figs. 1a and 2a). However, DW of 10C-treated plants reached a maximum at $144 \mathrm{~h}$ and then declined. Seedlings of both crops treated at 2 and $6 \mathrm{C}$ lost root DW when the time at chilling was longer than $48 \mathrm{~h}$.

When seedlings chilled at 2 and $6 \mathrm{C}$ were returned to $26 \mathrm{C}$ for 24 $\mathrm{h}$, root DW declined in those seedlings chilled for more than $48 \mathrm{~h}$ (Figs. $1 \mathrm{~b}$ and $2 \mathrm{~b}$ ). At the end of $192 \mathrm{~h}$ of chilling and after $24 \mathrm{~h}$ at $26 \mathrm{C}$, DW of seedlings roots chilled at $2 \mathrm{C}$ represented $<10 \%$ those at $15 \mathrm{C}$. After $96 \mathrm{~h}$ at 2 or $6 \mathrm{C}$, the roots of squash and cucumber seedlings were irreversibly damaged and lost the ability to resume growth after being returned to $26 \mathrm{C}$.

Effect of chilling on ion leakage. The loss of ions from chilled roots, as measured by electrical conductivity, increased after $24 \mathrm{~h}$

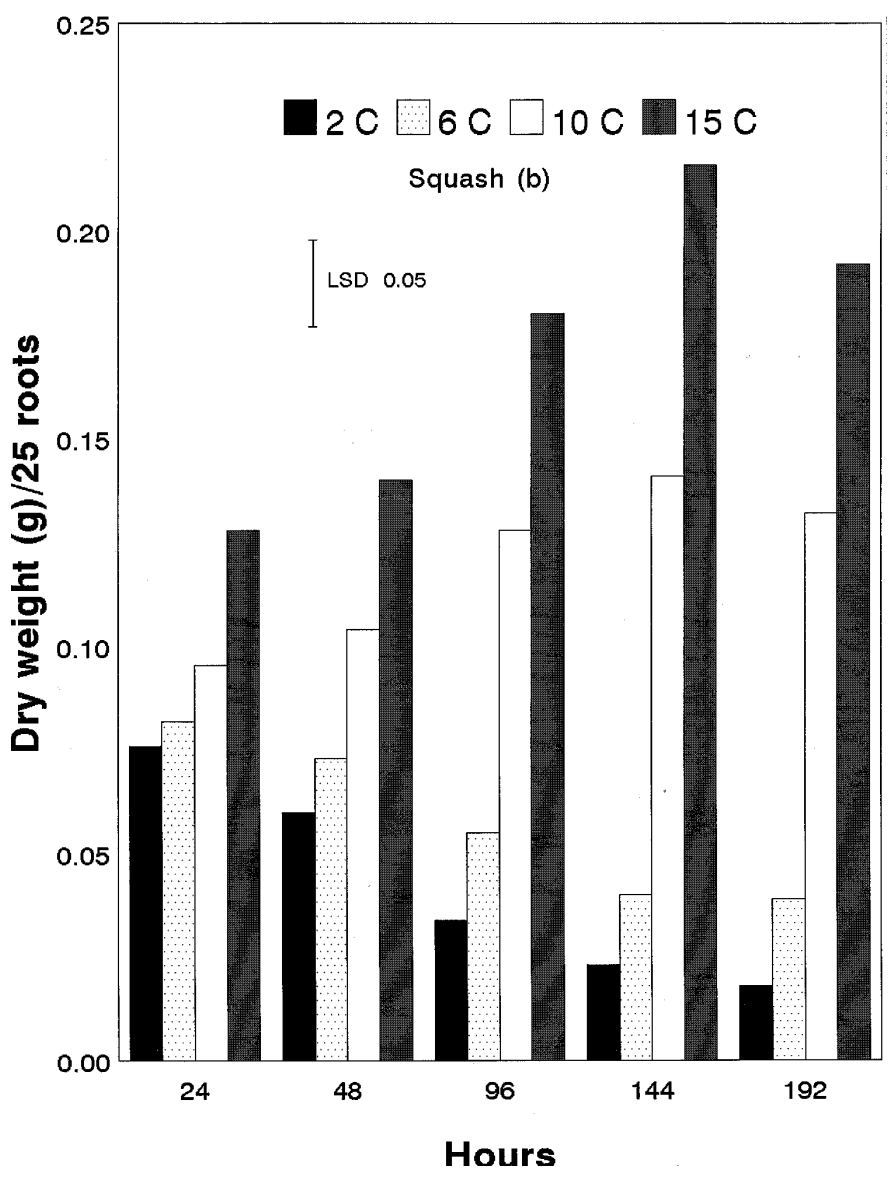

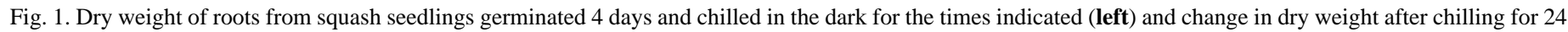
$h$ at 26C (right). Data represent dry weight of roots from 25 seedlings. Each treatment was replicated three times. 

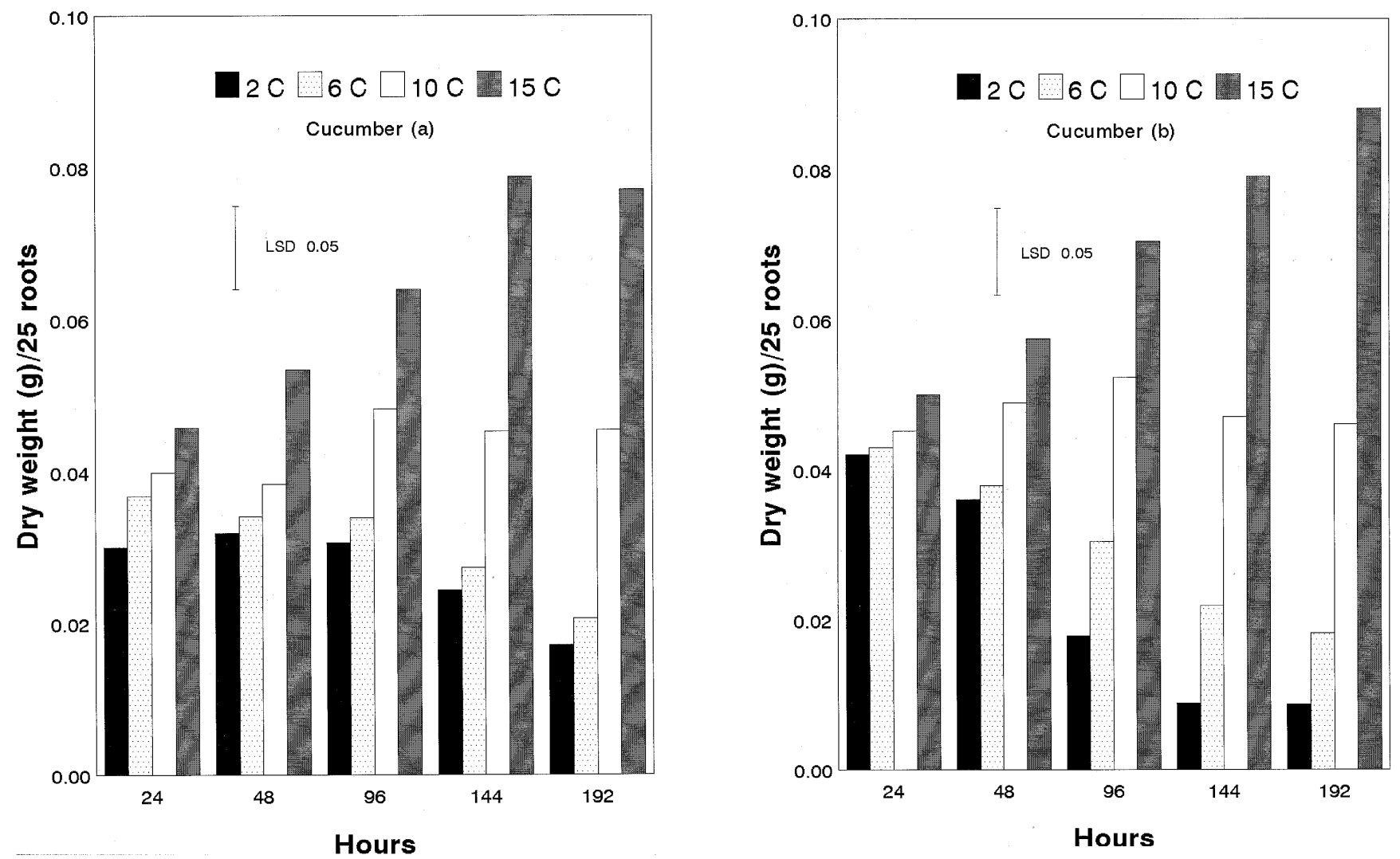

Fig. 2 . Dry weight of roots from cucumber seedlings germinated 4 days and chilled in the dark for the times indicated (left) and change in dry weight after chilling for $24 \mathrm{~h}$ at $26 \mathrm{C}$ (right). Data represent dry weight of roots from 25 seedlings. Each treatment was replicated three times.

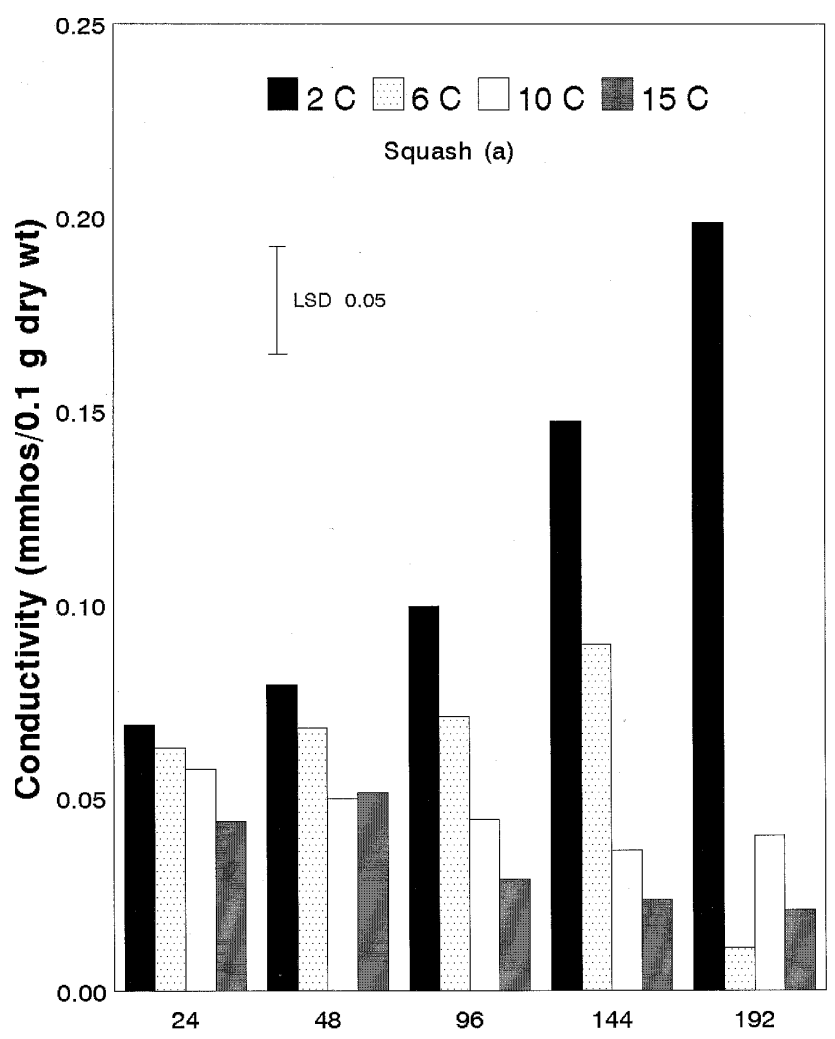

Hours

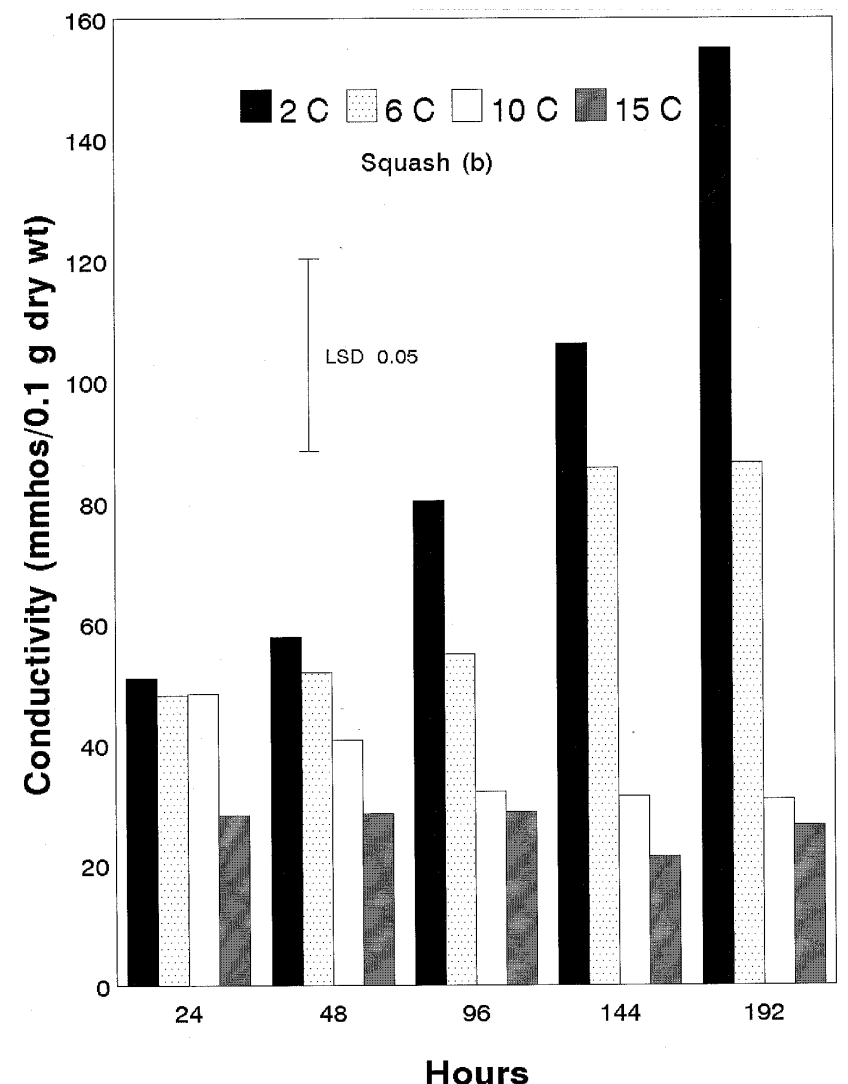

Fig. 3. Electrolyte leakage from squash roots chilled in the dark for five time periods (left), and change in conductivity after chilling for $24 \mathrm{~h}$ at $26 \mathrm{C}$ (right). Each experimant was replicated three times using 25 seedlings per sample. 

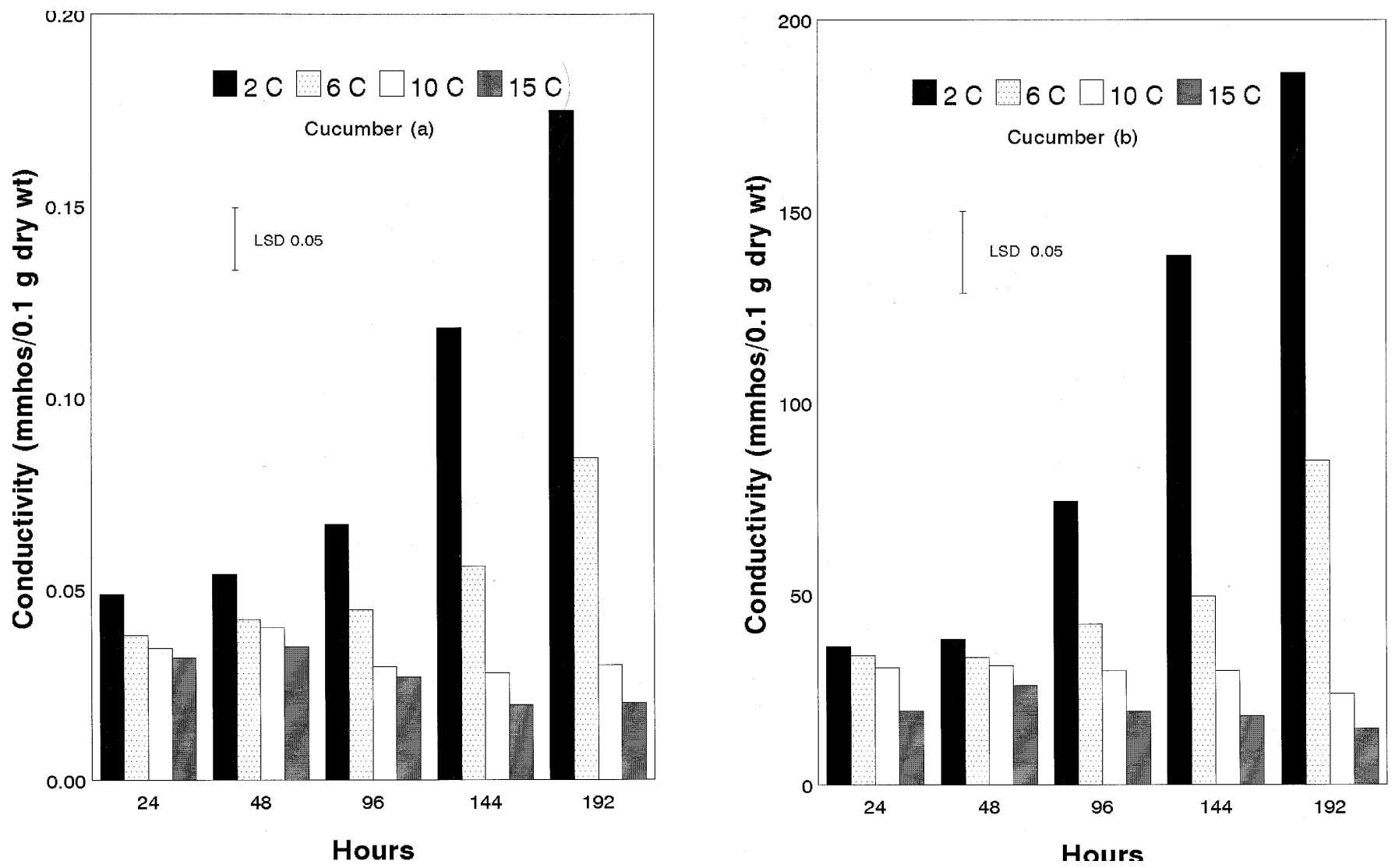

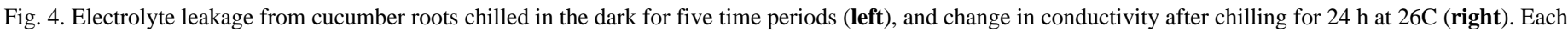
experiment was replicated three times using 25 seedlings per sample.

of chilling only at 2 and $6 \mathrm{C}$ for squash (Fig. 3a) and after $48 \mathrm{~h}$ for cucumber (Fig. 4a). There was no increase in leakage of either species at 10 and $15 \mathrm{C}$ even after $192 \mathrm{~h}$.

When seedlings were rewarmed to $26 \mathrm{C}$ for $24 \mathrm{~h}$, ion leakage from $2 \mathrm{C}$ - and 6C-treated seedlings increased in both species (Fig. $3 \mathrm{~b}$ and $4 \mathrm{~b}$ ). In contrast, ion leakage decreased from roots held at 10 or $15 \mathrm{C}$, especially at the longer treatment times.

Similar results were obtained when leakage of organic compounds was measured by absorbance at $280 \mathrm{~nm}$ (Figs. 5a and 6a). Absorbance increased considerably after $96 \mathrm{~h}$ at 2 and $6 \mathrm{C}$, regardless of whether the seedlings experienced a postchilling treatment at $26 \mathrm{C}$ for $24 \mathrm{~h}$ (Fig. $5 \mathrm{~b}$ and $6 \mathrm{~b}$ ). For roots of squash seedlings, the concentration of $280 \mathrm{~nm}$ absorbing solutes remained unchanged with increasing treatment time at 10 and $15 \mathrm{C}$, even for seedlings rewarmed to $26 \mathrm{C}$ (Fig. $5 \mathrm{a}$ and b). However, for roots of seedlings treated at 2 and $6 \mathrm{C}$, there was a progressive increase in leakage after $48 \mathrm{~h}$ of treatment.

To assure that the chilling-temperature effects were not the result of abrupt temperature changes, an experiment was conducted in which the temperature of chilled seedlings was increased stepwise from the chilling temperature to 26C. After $96 \mathrm{~h}$ of chilling at $2 \mathrm{C}$ and warming to $26 \mathrm{C}$ in steps, leakage, absorbance, and dry-weight changes for both species were not significantly different from chilled seedlings transferred directly to 26C (data not shown).

Effect of chilling on RWC. Roots of seedlings held at 15C exhibited a loss in RWC over the 4-day treatment period (Table 1). Roots chilled at 2C showed a loss in RWC during the first $48 \mathrm{~h}$ of treatment and an apparent increase in relative water content at 72 and $96 \mathrm{~h}$. A similar effect was observed in roots held at $10 \mathrm{C}$ for $96 \mathrm{~h}$.
Specific ion leakage. The quantity of ions leaked was significantly higher from roots held at $2 \mathrm{C}$ than at the other temperatures, but the absolute amounts were different for each species (Table 2). Exudation of $\mathrm{Na}^{+}, \mathrm{K}^{+}$, and $\mathrm{Mg}^{+}$was higher from roots held at $2 \mathrm{C}$ than those held at 10 and $15 \mathrm{C}$. $\mathrm{Na}^{+}$and $\mathrm{K}^{+}$constituted the majority of ions leaked from chilled roots, and the total ionic leakage increased in samples chilled at $2 \mathrm{C}$ for $144 \mathrm{~h}$. This effect was larger with cucumber than squash. Leakage of measured anions was less than cations for both plant species. However, at 2C, the total measured anionic leakage was always higher from cucumber roots. Calcium was not detected by the methodology used.

\section{Discussion}

Roots of cucumber and squash seedlings show similar responses to chilling as determined by the parameters tested in this study. Both crops were sensitive during early seedling development and lost their ability to recover when more favorable temperatures were restored. Furthermore, loss of organic and inorganic compounds increased regardless of whether seedlings received the postchilling treatment at 26C.

The browning observed in roots of seedlings stressed at $10 \mathrm{C}$ may be related to an alteration in the biosynthesis and/or oxidation of phenolic compounds. Increased presence of phenolic compounds has been reported in eggplant under chilling temperatures and may affect cell membranes and mitochondrial activity (Abe, 1990). An increase in the concentrations of two precursors of enzymes involved in the synthesis of phenolic compounds was observed in potato, sweetpotato, and apple fruit under chilling conditions (Graham and Patterson, 1982). 

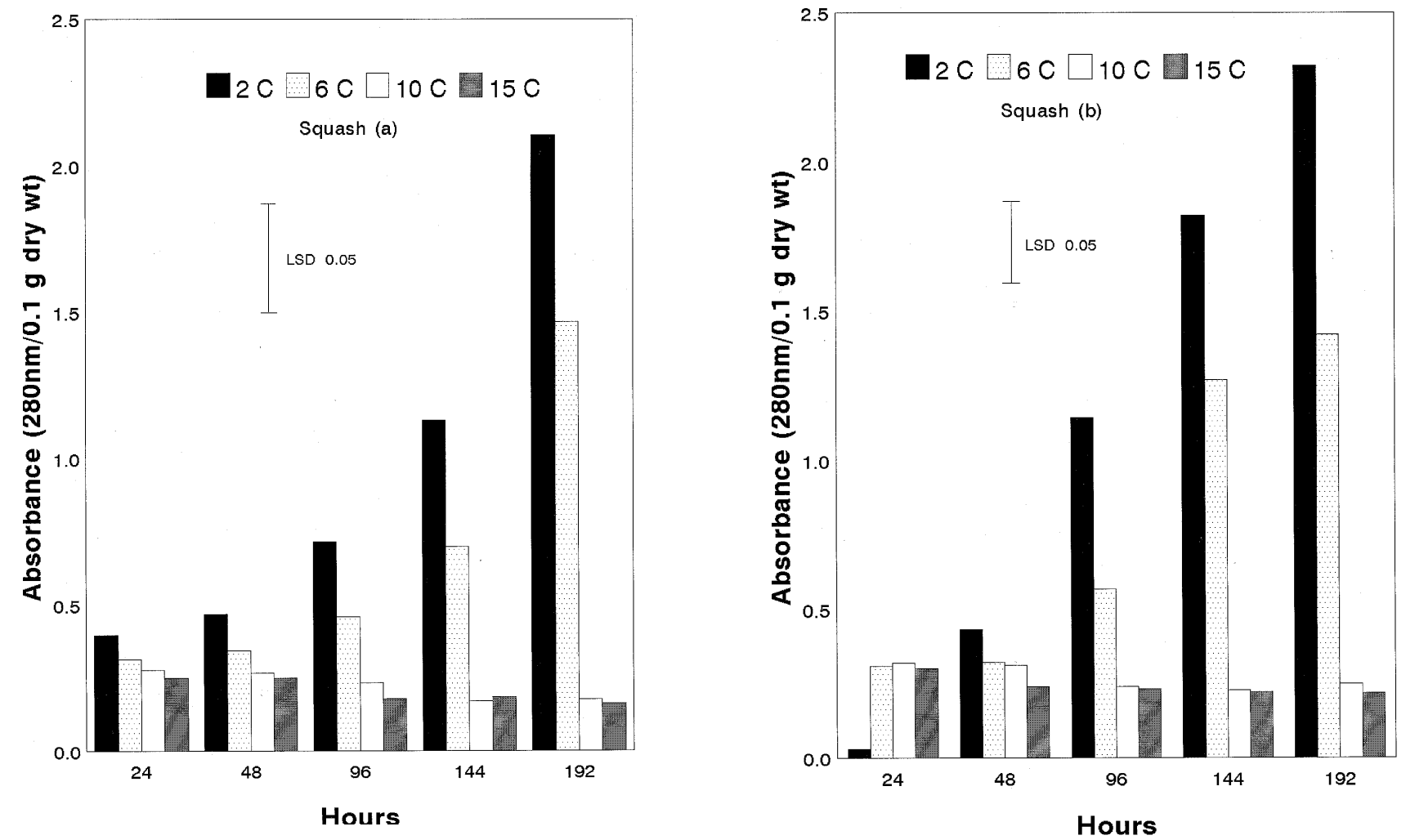

Fig. 5. Absorbance at $280 \mathrm{~nm}$ leachate from roots of squash seedlings chilled in the dark for five time periods (left), and change in absorbance for $24 \mathrm{~h}$ at $26 \mathrm{C}$ (right). Each experiment was replicated three times using 25 seedlings per sample.
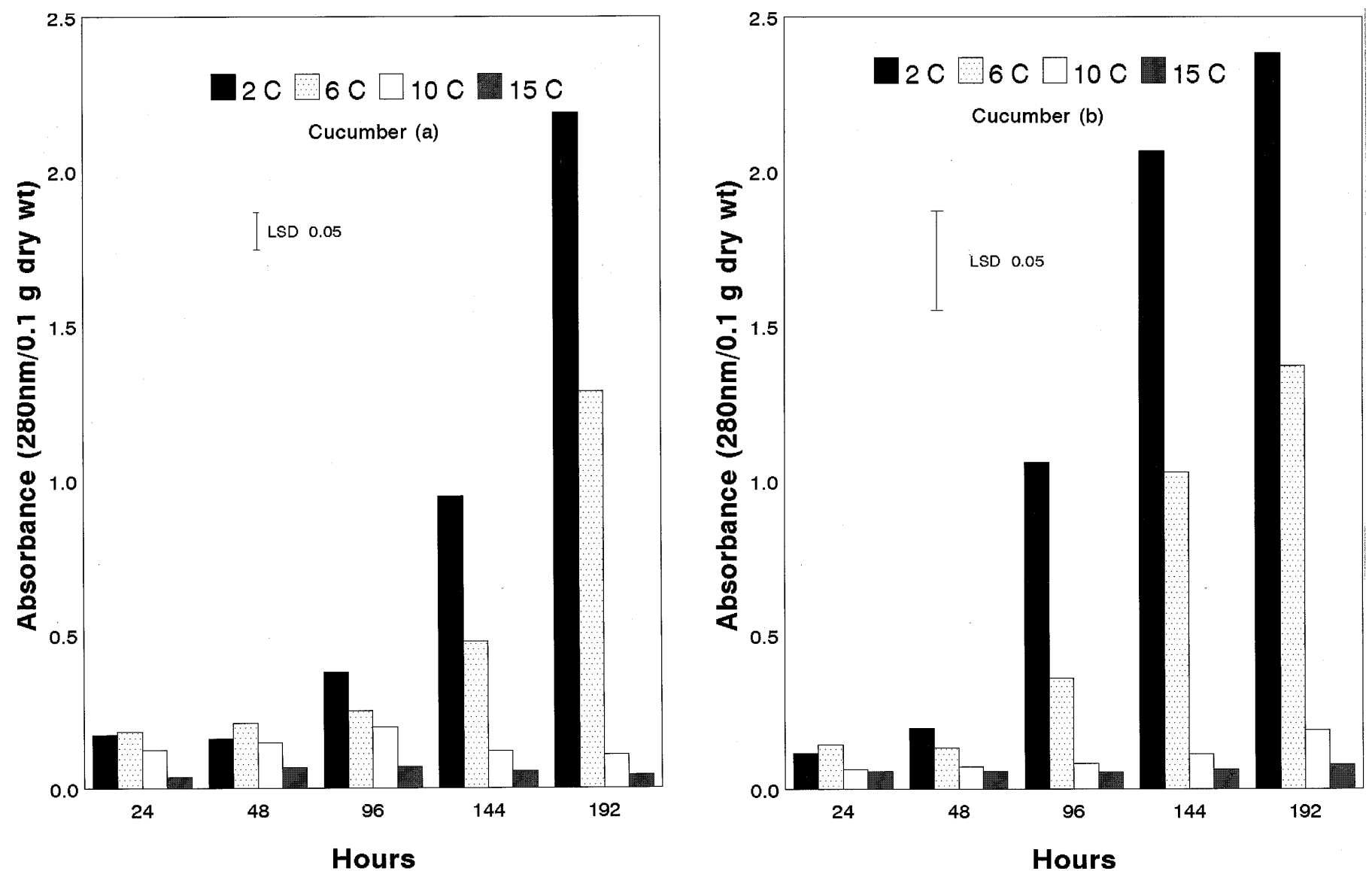

Fig. 6. Absorbance at $280 \mathrm{~nm}$ leachate from roots of cucumber seedlings chilled in the dark for five time periods (left), and change in absorbance for $24 \mathrm{~h}$ at $26 \mathrm{C}$ (right). Each experiment was replicated three times using 25 seedlings per sample. 
Table 1. Relative water content of cucumber roots. Seeds were germinated at $26 \mathrm{C}$ for 3 days and then held at 2,10 , or $15 \mathrm{C}$ for 24 to $96 \mathrm{~h}$. A sample of 21 roots was excised and placed in distilled water for $4 \mathrm{~h}$ in the dark. The experiment was replicated four times.

\begin{tabular}{lccc}
\hline \hline Time & \multicolumn{3}{c}{ Temperature $\left({ }^{\circ} \mathrm{C}\right)$} \\
\cline { 2 - 4 }$(\mathrm{h})$ & \multicolumn{1}{c}{2} & 10 & 15 \\
\hline 24 & $98.3 \mathrm{a}^{\mathrm{z}}$ & $97.8 \mathrm{a}$ & $97.5 \mathrm{~b}$ \\
48 & $93.5 \mathrm{~b}$ & $91.0 \mathrm{~b}$ & $91.2 \mathrm{~b}$ \\
72 & $103.7 \mathrm{a}$ & $92.2 \mathrm{~b}$ & $90.2 \mathrm{~b}$ \\
96 & $105.5 \mathrm{a}$ & $94.6 \mathrm{~b}$ & $88.7 \mathrm{c}$
\end{tabular}

$\overline{{ }^{\mathrm{z}} \text { Means followed by the same letter are not significantly different based on }}$ $P<0.05$, LSD.

Barlow and Adams (1989) reported that cell proliferation and root elongation occurred at $5 \mathrm{C}$ in the primary root meristem of Zea mays. Short periods of chilling did not restrict cellular activity in maize even though cell division may not occur when normal temperatures are restored (Creencia and Bramlage, 1971). Based on root DW of treated seedlings (Figs. $1 \mathrm{a}$ and $\mathrm{b}$ and $2 \mathrm{a}$ and $\mathrm{b}$ ), 10 and $15 \mathrm{C}$ were not restrictive temperatures for root growth. Root growth continued at these temperatures and when returned to 26C, although at a slower rate.

The time/temperature interaction was an important determinant of the amount of damage observed with both plant species tested. A greater reduction in root growth was observed in plants chilled for $96 \mathrm{~h}$ or longer at 2 and 6C. Irwin and Price (1983) reported that pepper seedling growth was greatly reduced after chilling for 4 days at 0C. Harrington and Kihara (1959) using muskmelon and pepper germinated 24 or $48 \mathrm{~h}$ at $25 \mathrm{C}$ and chilled at 0,5 , and $10 \mathrm{C}$ for 3 to 30 days reported that cells behind the root tip collapsed and rotted in many seedlings after being transferred to warm temperatures.

The dramatic loss of root DW in our studies after $2 \mathrm{C}$ for $48 \mathrm{~h}$ could be attributed to an alteration of the ratio between damaged cells and new tissue. Similar results were reported by Barlow and
Adam (1989) with maize roots chilled at 5C.

Alterations of membrane permeability and membrane integrity as a result of chilling time/temperature interactions were evident in this study. During the first $48 \mathrm{~h}$ of chilling at $2 \mathrm{C}$, seedlings apparently could temporarily cope with this stress since leakage did not increase until after $96 \mathrm{~h}$ at 2C (Figs. 3a, 4a, 5a, and 6a). Increased ion leakage could be an indication of membrane damage.

After chilling at 2 and $6 \mathrm{C}$, warm temperatures magnified the effect on roots, particularly by increasing membrane permeability (Figs. 3b, 4b, 5b, and 6b). This effect has been frequently reported by others (Herner, 1990; Wolk and Herner, 1982).

For periods less than $48 \mathrm{~h}$ at $2 \mathrm{C}$, cucumber roots maintained a physical integrity that allowed the roots to retain water and solutes (Table 1). Roots of seedlings growing at $15 \mathrm{C}$ exhibited a reduction in the RWC, presumably due to continued root growth and the accumulation of DW. Roots of seedlings exposed to $2 \mathrm{C}$ for more than $48 \mathrm{~h}$ lost their cellular/membrane integrity such that water and solutes leaked out into the surrounding media and could have accounted for an apparent increase in RWC.

High leakage rates of inorganic ions are often reported in chilling studies (Herner, 1990; Wolk and Herner, 1982). Leakage of $\mathrm{Na}^{+}, \mathrm{K}^{+}$, and $\mathrm{Mg}^{+2}$ analyzed in this study was higher than that of $\mathrm{Cl}^{-}, \mathrm{PO}_{4}^{-2}$, and $\mathrm{SO}_{4}^{-2}$ from tissue chilled at $2 \mathrm{C}$. This loss of ionic components may contribute to a loss of the cellular ionic balance, influencing enzymatic processes or regulatory pathways (Raison, 1980).

In conclusion, many contributing factors may account for the morphological and physiological responses discussed in this report. Alterations in cell structure, division, and differentiation of seedling roots in both crops could be associated with growth reduction at the most severe chilling temperature. Increased leakage suggests a breakdown in membrane integrity and/or loss of function of ion pumps or as a result of an effect on respiration/ energy conservation/release. Due to an alteration in the respiratory process, energy substrates in those tissues may be consumed, leading to irreversible damage.

Table 2. Leakage of specific ions from 25 roots of squash and cucumber seedlings exposed to 2, 10, and 15C for two time periods. Roots were excised and placed in deionized water for $4 \mathrm{~h}$ and analyzed by atomic absorption spectrophotometry. Data represent three replications.

\begin{tabular}{|c|c|c|c|c|c|c|c|}
\hline \multirow{3}{*}{$\begin{array}{l}\text { Time } \\
\text { (h) }\end{array}$} & \multirow{3}{*}{$\begin{array}{c}\text { Temp } \\
\left({ }^{\circ} \mathrm{C}\right)\end{array}$} & \multicolumn{6}{|c|}{ Ionic content $\left(\mathrm{mg} \cdot \mathrm{liter}^{-1}\right)$} \\
\hline & & \multicolumn{3}{|c|}{ Cations } & \multicolumn{3}{|c|}{ Anions } \\
\hline & & $\mathrm{Na}^{+}$ & $\mathrm{K}^{+}$ & $\mathrm{Mg}^{+2}$ & $\mathrm{Cl}^{-}$ & $\mathrm{PO}_{4}^{-2}$ & $\mathrm{SO}_{4}^{-2}$ \\
\hline \multicolumn{8}{|c|}{ Squash } \\
\hline \multirow[t]{3}{*}{48} & 2 & $16.6 \mathrm{a}^{\mathrm{z}}$ & $32.3 \mathrm{a}$ & $0.9 \mathrm{a}$ & $2.8 \mathrm{a}$ & $3.0 \mathrm{a}$ & $1.1 \mathrm{a}$ \\
\hline & 10 & $8.4 \mathrm{~b}$ & $22.0 \mathrm{~b}$ & $0.5 \mathrm{~b}$ & $1.5 \mathrm{~b}$ & $1.3 \mathrm{~b}$ & $0.4 \mathrm{~b}$ \\
\hline & 15 & $9.1 \mathrm{~b}$ & $26.8 \mathrm{~b}$ & $0.7 \mathrm{~b}$ & $1.8 \mathrm{~b}$ & $2.3 \mathrm{~b}$ & $0.5 \mathrm{~b}$ \\
\hline \multirow[t]{3}{*}{144} & 2 & $21.9 \mathrm{a}$ & $38.4 \mathrm{a}$ & $1.8 \mathrm{a}$ & $2.3 \mathrm{a}$ & $6.3 \mathrm{a}$ & $1.3 \mathrm{a}$ \\
\hline & 10 & $6.6 \mathrm{~b}$ & $20.8 \mathrm{~b}$ & $0.4 \mathrm{~b}$ & $1.7 \mathrm{~b}$ & $1.5 \mathrm{~b}$ & $0.4 \mathrm{~b}$ \\
\hline & 15 & $5.2 \mathrm{~b}$ & $18.8 \mathrm{~b}$ & $0.2 \mathrm{~b}$ & $1.9 \mathrm{~b}$ & $1.5 \mathrm{~b}$ & $0.4 \mathrm{~b}$ \\
\hline \multicolumn{8}{|c|}{ Cucumber } \\
\hline \multirow[t]{3}{*}{48} & 2 & $22.9 \mathrm{a}$ & $17.6 \mathrm{a}$ & $1.7 \mathrm{a}$ & $4.3 \mathrm{a}$ & $5.4 \mathrm{a}$ & $1.2 \mathrm{a}$ \\
\hline & 10 & $11.3 \mathrm{~b}$ & $7.2 \mathrm{~b}$ & $0.7 \mathrm{~b}$ & $3.6 \mathrm{~b}$ & $3.1 \mathrm{~b}$ & $0.8 \mathrm{~b}$ \\
\hline & 15 & $5.9 \mathrm{~b}$ & $6.9 \mathrm{~b}$ & $0.4 \mathrm{~b}$ & $3.1 \mathrm{~b}$ & $3.3 \mathrm{~b}$ & $0.6 \mathrm{~b}$ \\
\hline \multirow[t]{3}{*}{144} & 2 & $46.5 \mathrm{a}$ & $28.2 \mathrm{a}$ & $3.8 \mathrm{a}$ & $10.3 \mathrm{a}$ & $10.9 \mathrm{a}$ & $2.6 \mathrm{a}$ \\
\hline & 10 & $10.6 \mathrm{~b}$ & $8.3 \mathrm{~b}$ & $0.2 \mathrm{~b}$ & $4.9 \mathrm{~b}$ & $3.7 \mathrm{~b}$ & $0.6 \mathrm{~b}$ \\
\hline & 15 & $7.6 \mathrm{~b}$ & $3.2 \mathrm{~b}$ & $1 \mathrm{~b}$ & $2.2 \mathrm{~b}$ & $2.3 \mathrm{~b}$ & $0.4 \mathrm{~b}$ \\
\hline
\end{tabular}

${ }^{\mathrm{z}}$ Means followed by the same letter are not significantly different based on $P<0.05$, LSD. 


\section{Literature Cited}

Abe, K. 1990. Ultrastructural changes during chilling stress. In: C.Y. Wang (ed.). Chilling injury of horticultural crops. CRC Press, Boca Raton, Fla.

Barlow, P.W. and J.S. Adam. 1989. The response of the primary root mersitem of Zea mays L. to various periods of cold. J. Expt. Bot. 40:8188.

Barrs, H.D. and P.E. Weatherley. 1962. A re-examination of the relative turgidity technique for estimating water deficits in leaves. Austral. J. Biol. Sci. 15:413-428

Bennett, M.A., V.A. Dritz, and N.W. Callan. 1992. Impact of seed treatments on crop establishment. HortTechnology 2:345-349.

Bolger, T.P., D.R. Upchurch, and B.L. McMichael. 1992. Temperature effects on cotton root hydraulic conductance. Environ. Expt. Bot. 32:49-54.

Bradow, J.M. 1990a. Chilling sensitivity of photosynthetic oil-seedlings. Cucurbitaceae J. Expt. Bot. 41:1595-1600.

Bradow, J.M. 1990b. Chilling sensitivity of photosynthetic oil-seedlings. Cotton and Sunflower. J. Expt. Bot. 41:1585-1593.

Chabot, J.F. and A.C. Leopold. 1985. Ultrastructural aspects of chilling injury in the soybean seed radicle. Amer. J. Bot. 72:1120-1126.

Creencia, R.P. and W.J. Bramlage. 1971. Reversibility of chilling injury to corn seedlings. Plant Physiol. 47:389-392.

Crevecoeur, M., R. Deltour, and R. Bronchart. 1983. Effects of subminimal temperature on physiology and ultrastructural of Zea mays embryo during germination. Can. J. Bot. 61:1117-1125.

Davies, N.L. and J.M. Wilson. 1984. Ultrastructural study of chilling injury in roots of Episcia reptans (Mart.). Planta 160:185-189.

Graham, D. and B.D. Patterson. 1982. Response of plants to low, nonfreezing temperatures: proteins, metabolism and acclimation. Ann. Rev. Plant Physiol. 33:347-372.

Harrington, J.F. and G.M. Kihara. 1959. Chilling injury of germinating muskmelon and pepper seed. Proc. Amer. Soc. Hort. Sci. 75:485-489.

Herner, R. 1990. The effects of chilling temperatures during seed germination and early seedling growth. In: C.Y. Wang (ed.). Chilling injury of horticultural crops. CRC Press. Boca Raton, Fla.

Jackman, R.L., R.Y. Yada, A. Marangoni, K.L. Parkin, and D.W. Stanley. 1988. Chilling injury. A review of quality aspects. J. Food Sci. 11:253277.

Kimball, S.L. and F.B. Salisbury. 1973. Ultrastructural changes of plants exposed to low temperatures. Amer. J. Bot. 60:1028-1033.

Luza, J.G., R. van Gorsel, V.S. Polito, and A.A. Kader. 1992. Chilling injury in peaches: A cytochemical and ultrastructural cell wall study. J. Amer. Soc. Hort. Sci. 117:114-118.

Markhart, III, A.H., E.L. Fiscus, A.W. Naylor, and P.J. Kramer. 1979. Effect of temperature on water and ion transport in soybean and broccoli systems. Plant Physiol. 64:83-87.

Markhart, III, A.H. 1986. Chilling injury: A review of possible causes. HortScience 21:1329-1333.

McWilliam, J.R., P.J. Kramer, and R.L. Musser. 1982. Temperatureinduced water stress in chilling-sensitive plants. Austral. J. Plant Physiol. 9:343-352.

Mistrik, I., M. Holobrada, and M. Ciamporova. 1992. The root in unfavourable conditions. In: J. Kolek and V. Kozinka (eds.). Physiology of the plant root system. Kluwer Academic Publishers. Dordrecht, The Netherlands.

Raison, J.K. and J.M. Lyons. 1986. Chilling injury: A plea for uniform terminology. Plant Cell Environ. 9:685-686.

Saltveit, Jr., M.E. and L.L. Morris. 1990. Overview on chilling injury of horticultural crops. In: Ch.Y. Wang (ed.). 1990. Chilling injury of horticultural crops. CRC Press. Boca Raton, Fla.

Wang, Ch.Y. (ed.). 1990. Chilling injury of horticultural crops. CRC Press. Boca Raton, Fla.

Wolk, W.D. and R.C. Herner. 1982. Chilling injury of germinating seeds and seedlings. HortScience 17:169-173. 